

University of Kentucky

UKnowledge

\title{
Cytomegalovirus Serostatus, Inflammation, and Antibody Response to Influenza Vaccination in Older Adults: The Moderating Effect of Beta Blockade
}

\author{
Rebecca G. Reed \\ University of Kentucky, rebecca.reed@uky.edu \\ Richard N. Greenberg \\ University of Kentucky, rngree01@uky.edu \\ Suzanne C. Segerstrom \\ University of Kentucky, segerstrom@uky.edu
}

Follow this and additional works at: https://uknowledge.uky.edu/psychology_facpub

Part of the Behavior and Behavior Mechanisms Commons, Neuroscience and Neurobiology Commons, and the Psychology Commons

Right click to open a feedback form in a new tab to let us know how this document benefits you.

\section{Repository Citation}

Reed, Rebecca G.; Greenberg, Richard N.; and Segerstrom, Suzanne C., "Cytomegalovirus Serostatus, Inflammation, and Antibody Response to Influenza Vaccination in Older Adults: The Moderating Effect of Beta Blockade" (2017). Psychology Faculty Publications. 169.

https://uknowledge.uky.edu/psychology_facpub/169

This Article is brought to you for free and open access by the Psychology at UKnowledge. It has been accepted for inclusion in Psychology Faculty Publications by an authorized administrator of UKnowledge. For more information, please contact UKnowledge@lsv.uky.edu. 
Cytomegalovirus Serostatus, Inflammation, and Antibody Response to Influenza Vaccination in Older Adults: The Moderating Effect of Beta Blockade

\section{Digital Object Identifier (DOI)}

https://doi.org/10.1016/j.bbi.2016.09.025

Notes/Citation Information

Published in Brain, Behavior, and Immunity, v. 61, p. 14-20.

(c) 2016 Elsevier Inc. All rights reserved.

This manuscript version is made available under the CC-BY-NC-ND 4.0 license https://creativecommons.org/licenses/by-nc-nd/4.0/.

The document available for download is the author's post-peer-review final draft of the article. 


\title{
Cytomegalovirus Serostatus, Inflammation, and Antibody Response to Influenza Vaccination in Older Adults: The Moderating Effect of Beta Blockade
}

\author{
Rebecca G. Reed ${ }^{a,}{ }^{,}$, Richard N. Greenberg ${ }^{\mathrm{b}}$, and Suzanne C. Segerstrom ${ }^{\mathrm{a}}$ \\ aDepartment of Psychology, College of Arts and Sciences, University of Kentucky, Lexington, KY \\ bInfectious Diseases Division, College of Medicine, University of Kentucky, Lexington, KY
}

\begin{abstract}
Cytomegalovirus (CMV) has been implicated as a factor in immunosenescence, including poor antibody response to vaccination and higher immune activation and inflammation. Some people may be more or less vulnerable to the negative effects of CMV. The present investigation tested the effects of beta-blocker use and chronological age on the associations between CMV and immunity in adults aged 60-91 ( $\mathrm{N}=98 ; 69 \%$ CMV seropositive) who were administered the trivalent influenza vaccine for up to 5 years. Peak antibody response, corrected for baseline, and spring (persistent) antibody response, corrected for peak, were assessed, as well as beta- 2 microglobulin $(\beta 2 \mu)$ and interleukin-6 (IL-6). In multi-level models with years at Level 1 and people at Level 2, CMV serostatus did not predict peak antibody response, but there was a 3-way interaction between CMV serostatus, age, and beta-blockers. Age was negatively associated with peak antibody, but only among adults who were CMV seropositive and taking beta-blockers. CMV seronegative adults who were not taking beta-blockers had the highest antibody persistence. CMV serostatus was not associated with $\beta 2 \mu$ or IL-6. Results suggest that CMV+ serostatus may negatively compromise antibody response to a greater degree than inflammatory markers in older adults. Furthermore, older adults who take beta-blockers may be more vulnerable to negative effects of age and CMV on peak antibody response, perhaps by virtue of their underlying health condition.
\end{abstract}

\section{Keywords}

Cytomegalovirus; Aging; Antibody; Influenza; Vaccine; Inflammation; Beta blockade

\footnotetext{
"Corresponding author: Kastle Hall 125, Department of Psychology, University of Kentucky, Lexington, KY 40506, USA. rebecca.reed@uky.edu.

Publisher's Disclaimer: This is a PDF file of an unedited manuscript that has been accepted for publication. As a service to our customers we are providing this early version of the manuscript. The manuscript will undergo copyediting, typesetting, and review of the resulting proof before it is published in its final citable form. Please note that during the production process errors may be discovered which could affect the content, and all legal disclaimers that apply to the journal pertain.

Conflict of Interest

The authors declare no conflict of interest.
} 


\section{Introduction}

Cytomegalovirus (CMV) is an epidemic latent herpesvirus with age-related prevalence, ranging from 40\% (18-24 years old) to over 90\% (75-80 years old) (Badami et al., 2009). Unlike other herpesviruses, CMV is rarely associated with a symptomatic acute infection in immunocompetent hosts. It has been suggested that CMV co-evolved with its hosts, resulting in a relatively benign infection (Britt, 2008). However, CMV is not entirely benign. Latent CMV infection may have consequences for the aging immune system, as CMV is thought to drive immune senescence (Koch et al., 2007). Consequences include a high percentage of senescent $\mathrm{T}(\mathrm{CD} 8+\mathrm{CD} 28-$ or $\mathrm{CD} 8+\mathrm{CD} 57+)$ and natural killer (NK; CD56 ${ }^{\text {dim }}$ CD57+) cells in blood (Lopez-Vergès et al., 2011; Olsson et al., 2001; Wang, Taylor-Wiedeman, Perera, Fisher, \& Borysiewicz, 1993). The cytokine profile of senescent cells is more proinflammatory than non-senescent cells (Effros, 2012; Effros, Dagrarag, Spaulding, \& Man, 2005). CMV antibody titers correlate with proinflammatory cytokines in serum, as well as monocyte activation (de Pablo-Bernal et al., 2015; Trzonkowski et al., 2003). Ultimately, enhanced "inflammaging" due to CMV could increase risk for multiple health problems of older adulthood (Ershler \& Keller, 2000; Frasca \& Blomberg, 2016). Importantly, senescence-associated immune changes have also been framed as immune adaptation, such that the sustained inflammatory state of older adults' innate immune system may be the necessary prerequisite for an acceptable level of functioning of the adaptive immune response (Fulop et al., 2016). Nevertheless, the absolute number of senescent cells is so much increased that they themselves may cause pathology as a result of their higher ability to produce inflammatory mediators (Pawelec, Larbi, \& Derhovanessian, 2010).

CMV may also contribute to poor antibody production by B cells (Simons \& Reynolds, 1990). CMV antibody titers correlated negatively with antibody response to influenza vaccination among both older (65-99 years) and younger (19-40 years) adults (Trzonkowski et al., 2003). However, in another sample of older (62-89 years) and younger (20-30 years) adults, CMV+ serostatus was associated with more antibody production after vaccination among younger adults but not among older adults (Furman et al., 2015). Among older (7788 years) long-term care residents (den Elzen et al., 2011) and adults aged 69 years (Strindhall et al., 2016), CMV+ serostatus was unrelated to vaccine antibody responses. Differences between older and younger adults in the effects of latent CMV infection on antibody response to vaccine may be a consequence of duration of latent infection (Furman et al., 2015) or of an interactive effect with chronological age.

These varying relationships between CMV and antibody response to vaccination among older adults suggest the existence of factors that make individuals more or less susceptible to effects of latent CMV infection. One such factor is activation of the sympathetic nervous system. Stress-induced catecholamines stimulate CMV gene expression via the $\beta_{2^{-}}$ adrenergic receptor $\left(\beta_{2} \mathrm{AR}\right)$ (Prösch et al., 2000). Mental and physical stressors can induce latent herpes simplex virus reactivation via neuroendocrine factors, including catecholamines (Freeman, Sheridan, Bonneau, \& Hendricks, 2007). Treatment with propranolol, a $\beta$-adrenergic receptor blocker, reduced herpes simplex virus type 1 reactivation in an animal model (Gebhardt \& Kaufman, 1995). In vitro, propranolol abrogated the stimulatory effect of epinephrine and norepinephrine on human CMV activity 
(Prösch et al., 2000). Thus, for older adults infected with CMV, beta-blockers may be protective against $\mathrm{CMV}$-induced immune dysregulation (i.e., lower antibody titers to vaccination and higher inflammation) insofar as blockade of the $\beta_{2} \mathrm{AR}$ may prevent CMV reactivation.

However, beta-blockers may also interfere with sympathetically induced expression of costimulatory molecules (e.g., B7-2) on B cells and exert timing-dependent suppression of B cell antibody responses (Sanders, Kasprowicz, Kohm, \& Swanson, 2001). In the present sample of older adults, beta-blockers correlated with less antibody production in the month after influenza vaccination (Segerstrom, Hardy, Evans, \& Greenberg, 2012). However, that analysis did not consider CMV serostatus or longer-term antibody persistence.

The present study therefore tested the effects of chronological age, CMV serostatus, and beta-blocker use among older adults on two aspects of immunosenescence: antibody production after influenza vaccination and markers of immune activation and inflammation (beta- 2 microglobulin $[\beta 2 \mu]$ and interleukin- 6 [IL-6]). We focused on $\beta 2 \mu$ and IL-6 because they are found in higher levels in healthy older compared with younger adults (Dong et al., 2016; Forsey et al., 2003), are related to clinically relevant health outcomes in older adults, including frailty and age-related cognitive dysfunction (Cohen, Harris, \& Pieper, 2003; Smith et al., 2015), and one is produced by both immunocytes and adipose tissue (IL-6; O'Connor et al., 2009), whereas the other $(\beta 2 \mu)$ is produced by immunocytes. The first hypothesis was that older age and CMV+ serostatus would correlate with lower antibody production after vaccination and higher levels of $\beta 2 \mu$ and IL-6 (Frasca \& Blomberg, 2016). The second hypothesis was that beta-blockers would blunt the effects of CMV on antibody production and inflammatory markers. However, because beta blockade may have also adverse effects on antibody production in earlier stages of B cell activation and maturation (Sanders et al., 2001; Segerstrom et al., 2012), exploratory analyses tested these hypotheses both with regard to antibody production in the short term (i.e., weeks after vaccination) and antibody persistence in the long term (i.e., months after vaccination).

\section{Materials and methods}

\subsection{Participants}

Participants were 98 older adults recruited through the clinics and volunteer subject pool of the Sanders-Brown Center on Aging and administered the trivalent influenza vaccine for up to 5 years ( $n=325$ person-years; see Table 1$)$. The sample was on average 74 years old at enrollment (range $=60-91)$. The majority were female $(62 \%)$, Caucasian $(95 \%)$, and CMV seropositive (69\%).

\subsection{Procedures}

All procedures were approved by the University of Kentucky Institutional Review Board. Participants were recruited continuously from 2001 to 2007. Those older adults who had expressed interest in research participation to the Center on Aging were contacted by phone and screened. Inclusion criteria were: age 60 or older, married, and willing to be vaccinated against influenza. Exclusion criteria were: diseases that affect the immune system (e.g., 
autoimmune disease, cancer); chemotherapy or radiation in the 5 years prior to enrollment; immunomodulatory medications including opioids and steroids; or more than two of the following classes of medications: psychotropics, anti-hypertensives, hormone replacement, or thyroid supplements. These criteria excluded major influences on immune responses and allowed reasonably healthy adults to participate in the study.

Participants were interviewed semi-annually in their homes and provided a list of current medications at each visit. Vaccinations were performed annually from 2001 to 2008. Nurses administered the commercially available, seasonal, trivalent influenza vaccine in the participant's home or in the clinic, whichever the participant preferred. Blood draws were taken immediately before vaccination, 2 and 4 weeks after vaccination, and in the spring following vaccination (late March to early April; $M=170.8$ days after vaccination, SD $=13.8$ ).

\subsection{Measures}

2.3.1 Demographics and medications-Subjects reported their date of birth (used to calculate age at each wave); gender; and height and weight (used to calculate body mass index $[\mathrm{BMI}])$ at their first semi-annual visit. Beta-blocker and statin use at each visit was coded by a study nurse from participants' medication lists. Blood draws were matched to medication lists from the interview closest in time. Beta-blocker and statin use were both treated as time-varying variables. However, most participants were on consistent medications throughout the study period: $68.3 \%$ consistently off beta-blockers and $19.2 \%$ consistently on beta-blockers; $43.3 \%$ consistently off statins and $28.0 \%$ consistently on statins.

Of those individuals on beta-blockers, $52 \%(n=12)$ were on generic metoprolol, $13 \%(n=3)$ were each on atenolol, carvediolol, and propranolol, and $4 \%(n=1)$ were each on acebutolol and bisoprolol. The majority of individuals on metoprolol $(n=11)$ and all individuals on propranolol ( $n=3$ ) were CMV seropositive; the CMV serostatus of individuals on the each of the remaining beta-blockers (atenolol, carvediolol, acebutolol, bisoprolol) were roughly split between seropositive and seronegative. The average dosage per day was $50 \mathrm{mg}$ ( $S D=$ 66 , median $=25$, mode $=50$, range $=3.125-400$ ). The majority $(47 \%)$ were on betablockers to treat high blood pressure, and the remaining were either on beta-blockers for arrhythmias (29\%) or did not know or did not report why they were on beta-blockers (24\%).

2.3.2 Cytomegalovirus (CMV) serostatus-CMV IgG titers were assessed by enzyme immunoassay in a single batch (EIA-1797, DRG International, Inc.). Median inter-assay CV was 2.8 (range $=0.1-10.2)$ and median intra-assay CV was $3.4($ range $=1.8-7.5)$. The first and last archived longitudinal samples from each participant were assayed. Seronegative status was defined as titer $<1 \mathrm{IU} / \mathrm{ml}$; seropositive status was defined as titer $>1 \mathrm{IU} / \mathrm{ml}$ in both samples and $\geq 10 \mathrm{IU} / \mathrm{ml}$ in at least 1 sample. Two participants were eliminated from analysis because they seroconverted during the study.

2.3.3 Antibody response: Peak and persistence-Antibody titers against the H1N1, $\mathrm{H} 3 \mathrm{~N} 2$, and B vaccine components were assayed separately by hemagglutination inhibition tests. Specific vaccine strains included the following (WHO, 2016): H1N1 (2001-2007: 
A/New Caledonia/20/99; 2007-2008: A/Solomon Islands/3/2006), H3N2 (2001-2004: A/ Moscow/10/99; 2004-2005: A/Fujian/411/2002; 2005-2006: A/California/7/2004; 20062008: A/Wisconsin/67/2005), and B (2001-2002: B/Sichuan/379/99; 2002-2004: B/ HongKong/330/2001; 2004-2006: B/Shanghai/361/2002; 2006-2008: B/Malaysia/ 2506/2004). Two antibody responses were examined: peak and persistent responses. Peak antibody was defined as the higher of the 2-week or 4-week post-vaccine titers. Antibody persistence was the spring titer. Characterization of the antibody responses in this sample has been previously described (Segerstrom et al., 2012). All antibody titers were standardized within specific vaccine formulation (e.g., A/New Caledonia/20/99) and then within strain (H1N1). Because all subjects had previously been vaccinated against influenza, and antibody response following vaccination in a partially seropositive sample depends highly on prior antibody levels, peak antibody response was corrected for baseline antibody level, and persistence was corrected for peak response (Beyer et al., 2004). All corrected antibody titers were reasonably correlated with each other within year (H1N1 with H3N2 was $r=.45 ; \mathrm{H} 1 \mathrm{~N} 1$ with B was $r=.40 ; \mathrm{H} 3 \mathrm{~N} 2$ with B was $r=.30$ ). Thus, the strain-specific vaccine titers were averaged to create reliable composites of peak response $(\alpha=.64)$ and persistence $(\mathrm{a}=.58)$ that were used in all analyses. Higher scores represent larger antibody responses. There was evidence of flu infection at two person-year observations, indexed by the serological criterion of a fourfold increase from peak to persistent raw antibody titers. Thus, the persistent antibody titers for those two person-year observations were not included in the standardization of antibody titers or in further analyses.

2.3.4 Inflammatory markers: $\beta 2 \mu$ and IL- $6-\beta 2 \mu$ and IL-6 were collected in serum. The present analysis used samples collected before influenza vaccination and approximately 6 months later. $\beta 2 \mu$ was assayed using enzyme linked immunosorbent assay (ELISA; ALPCO Diagnostics). Median inter-assay CV was 3.8 (range $=2.8-4.7$ ) and median intraassay CV was 2.3 (range $=1.3-3.1$ ). IL-6 was assayed with high-sensitivity ELISA (R \& D Systems). Median inter-assay CV across the study period was 6.44 (range $=3.1-13.3$ ) and median intra-assay $\mathrm{CV}$ was 2.17 (range $=1.4-3.7$ ). IL-6 was subjected to a $\log _{10}$ transformation to improve normality; the distribution of $\beta 2 \mu$ did not require transformation. Inflammatory marker data for waves at which individuals were currently suffering from acute infection $(n=12)$ were removed prior to analyses.

\subsection{Statistical Analyses}

Table 2 presents descriptive information for study variables. Data were analyzed in multilevel models to account for the repeated measures (i.e., years, Level 1) nested within individuals (Level 2). We implemented models in SAS PROC MIXED using maximum likelihood estimation, Kenward-Roger degrees of freedom, and an unstructured matrix for the random components (Singer, 2002). These models use all available data without the need for either list-wise deletion or data imputation (Singer \& Willett, 2003).

Null models with no predictors were used to estimate the intraclass correlations (ICC) for the four outcomes: peak antibody response, persistent antibody response, $\beta 2 \mu$, and IL-6. Subsequent models included age at each wave (centered around 74, the sample mean age at study entry), beta-blocker use, and CMV serostatus as main effects. Given that adipose 
tissue produces proinflammatory cytokines (O'Connor et al., 2009), models predicting IL-6 also controlled for BMI (grand mean centered). Models predicting IL-6 and $\beta 2 \mu$ also controlled for statin use, given potential anti-inflammatory effects (O'Connor et al., 2009). Separate models tested main effects of and interactions between age, beta-blockers, and CMV serostatus on antibody responses (peak and persistence), $\beta 2 \mu$, and IL-6. Models were run separately for each outcome variable. Following methods outlined by Aiken and West (1991), significant interactions were probed at meaningful levels of chronological age (60, 70,80 , and 90 years of age), beta-blocker use, and CMV serostatus.

\section{Results}

\subsection{Available Data}

The percentages of missing person-year observations for peak and persistent antibody responses and inflammatory markers were each between $22-26 \%$. The number of available data points for peak and persistent antibody responses did not differ across CMV serostatus (peak: $\mathrm{t}(96)=-1.68, \mathrm{p}=.10$; persistent: $\mathrm{t}(96)=-1.24, \mathrm{p}=.22$ ) nor beta-blocker use (peak: $\mathrm{t}(96)=.50, \mathrm{p}=.52$; persistent: $\mathrm{t}(96)=.32, \mathrm{p}=.75)$. In addition, the number of available data points for peak and persistent antibody responses did not correlate with age (peak: $r=-.02$; persistent: $\mathrm{r}=-.02$ ).

\subsection{Longitudinal Structure of Antibody Responses and Inflammation: Stability and Change}

Intraclass correlations from multilevel models with years at Level 1 and people at Level 2 indicated a minority of the variance in antibody response was due to stable between-person differences (27\% of peak; $38 \%$ of persistence), and a majority was due to within-person changes between years (73\% of peak; $62 \%$ of persistence). Conversely, a majority of the variance in $\beta 2 \mu$ was due to between-person differences (73\%), and a minority was due to within-person changes (27\%). The variance in IL-6 was more evenly split between betweenperson differences (43\%) and within-person changes (57\%).

\subsection{Peak Antibody Response}

There were no main effects of chronological age, beta-blocker use, or CMV serostatus on peak antibody response. There was, however, a significant 3-way interaction between chronological age, beta-blocker use, and CMV serostatus predicting peak antibody response $(\gamma=-.13, \mathrm{SE}=.05, \mathrm{t}(187)=-2.19, \mathrm{p}=.030)$. As shown in Figure 1, age was negatively associated with peak antibody production, but only among adults who were CMV seropositive and taking beta-blockers (simple age slope: $\gamma=-.08, \mathrm{SE}=.02, \mathrm{p}<.0001$ ).

\subsection{Spring Antibody Persistence}

Chronological age did not significantly predict antibody persistence, controlling for peak antibody. As predicted, CMV seropositive adults had less antibody persistence (main effect: $\gamma=-.35, \mathrm{SE}=.14, \mathrm{p}=.013$ ), and use of beta-blockers was also associated with less persistence (main effect: $\gamma=-.50, \mathrm{SE}=.25, \mathrm{p}=.044$ ). CMV serostatus and beta-blocker use were, however, qualified by a statistically significant interaction between them (interaction: $\gamma=.57, \mathrm{SE}=.28, \mathrm{t}(194)=2.01, \mathrm{p}=.046)$. As shown in Figure 2, CMV- adults who were not taking beta-blockers had the highest antibody persistence (estimate $=.25$ ): significantly 
higher than both CMV- adults taking beta-blockers (estimate $=-.31$; simple main effect: $\gamma=$ -.46, $\mathrm{SE}=.21, \mathrm{p}=.032$ ) and $\mathrm{CMV}+$ adults not taking beta-blockers (estimate $=-.08$; simple main effect: $\gamma=-.33, \mathrm{SE}=.12, \mathrm{p}=.006)$. $\mathrm{CMV}+$ adults had similar antibody persistence whether or not they were taking beta-blockers (simple main effect: $\gamma=.07, \mathrm{SE}=.15, \mathrm{p}=.62$ ).

\subsection{Inflammatory Markers: $\beta 2 \mu$ and IL- 6}

Older chronological age was associated with higher $\beta 2 \mu(\gamma=.017$, SE $=.008, t(90.3)=2.12$, $\mathrm{p}=.037)$ and IL-6 $(\gamma=.023, \mathrm{SE}=.009, \mathrm{t}(127)=2.38, \mathrm{p}=.019)$. Beta blocker use was also associated with higher $\beta 2 \mu(\gamma=.35, \mathrm{SE}=.105, \mathrm{t}(86.9)=3.36, \mathrm{p}=.001)$ and IL-6 $(\gamma=.28$, SE=. $121, \mathrm{t}(121)=2.31, \mathrm{p}=.023)$. There was no main effect of $\mathrm{CMV}$, or interactions with age or beta-blocker use, on $\beta 2 \mu$ or IL-6.

\section{Discussion}

The present study tested the effect of CMV serostatus, as well as its interactions with chronological age and beta blockade, on antibody responses to influenza vaccination and markers of immune activation $(\beta 2 \mu)$ and inflammation (IL-6) in healthy older adults. Results partially supported our hypotheses. Individuals who were CMV seropositive had poorer antibody persistence, although not poorer peak antibody. When the combinations of CMV serostatus, age, and beta blockade were considered, individuals who were CMV seropositive and who were taking beta-blockers were more susceptible to age-related decline in peak antibody. Contrary to predictions, CMV was not associated with $\beta 2 \mu$ or IL- 6 either by itself or in combination with age and beta blockade. The results implicate CMV in aspects of immunosenescence centered more on B cell function, especially memory function, than on immune activation and inflammatory markers in this sample of healthy, older adults.

$\mathrm{CMV}+$ serostatus was not associated with peak antibody response per se, but was associated with poorer antibody persistence. Others have reported no association between CMV serostatus and peak antibody response (Furman et al. 2015; Strindhall et al., 2016; Wald et al. 2013). However, these studies have not examined the effect of CMV serostatus on antibody persistence through the end of influenza season. Antibody persistence may contribute to clinical protection for over 6 months post-vaccination (Skowronski, Tweed,\& De Serres, 2008), with one recent report suggesting protection through at least one subsequent influenza season (i.e., 1.5 years post-vaccination; Sridhar et al., 2015); thus, persistence is an equally important aspect of the antibody response to investigate. Peak antibody after vaccination depends mainly on short-lived plasma B cells, whereas antibody persistence depends on CD27+ memory B cells and long-lived plasma cells. The number of memory B cells after vaccination correlated with antibody persistence for both pertussis and measles (Buisman, de Rond, Öztürk, ten Hulscher, \& van Binnendijk, 2009). CMV+ serostatus was negatively associated with predictive biomarkers of vaccine responses, including switched memory B cells (Frasca et al., 2015). T cell help is thought to be important for B cell memory; therefore, effects of CMV on the memory $\mathrm{T}$ cell population may account for its adverse effects on antibody persistence after vaccination (McHeyzerWilliams \& McHeyzer-Williams, 2007; Olsson et al., 2001). 
In the current study, markers of immune activation $(\beta 2 \mu)$ and inflammation (IL-6) were higher with older age, but CMV+ serostatus was not associated with $\beta 2 \mu$ or IL-6. This finding is contrary to previous research suggesting that CMV is positively associated with proinflammatory cytokine release, or "inflammaging", in older adults (Trzonkowski et al., 2003; van de Berg et al., 2010). However, in a recent 10-year longitudinal study of older adults, levels of proinflammatory cytokines increased over time independently of CMV serostatus (Bartlett et al., 2012). Another possibility is that inflammatory markers correlate with the length of time that an individual has been CMV seropositive or the degree of CMV activation, as opposed to serostatus (Bosch et al., 2013). Furthermore, inflammaging may not be reducible to a single cause (e.g., CMV) but rather the additive or synergistic effects of other chronic infections and diseases that can often take place simultaneously in older adults (Salvioli et al., 2013).

Based on previous research indicating that sympathetic nervous system activity may facilitate latent virus reactivation via costimulatory molecules on B-cells (Prösch et al., 2000), we predicted that beta-blockers would have an anti-viral and anti-inflammatory effect (Gebhardt \& Kaufman, 1995; Ohtsuka et al., 2001) and facilitate more desirable immune outcomes in CMV seropositive adults. However, older adults taking beta-blockers were more vulnerable to the effects of CMV and age on peak antibody response. Additionally, CMV seronegative adults taking beta-blockers had significantly less antibody persistence than those not taking beta-blockers, although this effect requires replication given the small number of people in the CMV-/BB+ subset of the present sample (see Table 1). Beta blockade was also positively associated with $\beta 2 \mu$ and IL-6. In the present sample, participants were not randomized to beta blockade, and its effects may have more to do with underlying pathophysiology (e.g., hypertension) than CMV reactivation. Older adults prescribed beta blockers may also have genetic, metabolic, or behavioral qualities associated with immune activation (Perk et al., 2012). To test this interpretation, we examined post hoc the relationship between beta blockade and general health as reflected in self-rated health ( $1=$ excellent, $5=$ poor) and the Chronic Disease Score (Clark et al., 1995). Controlling for age and CMV status in multilevel models, taking beta-blockers was associated with poorer self-rated health (2.51 vs. 2.23, $\mathrm{t}(307)=2.20, p=.03)$ and higher Chronic Disease Score (1360 vs. 942, $\mathrm{t}(309)=7.66, p<.0001)$. Therefore, beta blockade may index poor health in the present study. The findings suggest a need for experimental designs randomizing participants to beta blockade to tease apart effects of the actual drug versus underlying health conditions on aspects of immunosenescence. In addition, it may be that the therapeutic effect of beta blockade is conferred through long-term use; however, this remains an open question in subjects without cardiac issues. The availability of pre-clinical data and approved, safe, and inexpensive beta-antagonists with well-understood pharmacology and minimal side effects provide a favorable risk/benefit profile for clinical testing of beta blockade (Baker, Hill, \& Summers, 2011). Previous experimental designs have tested shorter-term beta blockade (in patients without confounding indication of cardiovascular issues) as an effective therapeutic in, for example, clinical oncology for cancer cachexia and immune outcomes in the perioperative period of breast cancer surgery (Stewart Coats et al., 2016; Zhou et al., 2016). 
The findings also call for additional research into the interaction of CMV with other, nonimmune health risks such as mood (depression, anxiety; Phillips, Carroll, Khan, \& Moss, 2008) or hypertension (Firth et al., 2016) in the promotion of immune senescence. In the present sample, individuals without either CMV or beta-blockers had the best antibody persistence. Likewise, individuals in this sample without either psychological distress or poor physical condition (sedentariness or high BMI) had the best peak antibody response (Segerstrom et al., 2012, Figures 2 and 3). Therefore, in this sample of older adults, interactions between risk factors took a form in which having a single risk factor was sufficient to compromise antibody responses to vaccination, and having two risk factors was not significantly worse than either one alone. Targeting a single risk factor, whether that be latent virus infection, comorbid health conditions, psychological distress, or health behavior, may not be sufficient to improve response to vaccination in older adults.

We cannot draw conclusions about the protective effects of the antibody titers in the current study as it is unknown if exposure to influenza may result in effective clinical immune responses. However, lower antibody titers may translate to poorer clinical outcomes upon exposure to influenza (Ohmit, Petrie, Cross, Johnson, \& Monto, 2011). In addition, these findings do have clinical implications for naturalistic interactions between beta blockade, CMV serostatus, and response to vaccination. Given the high prevalence of medication use among older adults (Qato et al., 2008), consideration of the effects of beta blockade on markers of immunosenescence is important. Although influenza vaccination prevents hospitalizations and deaths in older adults (Darvishian et al., 2014), those who mount a smaller antibody peak response to the vaccination may be at higher risk. Thus, beta blockers may not be an effective influenza vaccine adjuvant in CMV seropositive older adults when taken therapeutically for health conditions such as hypertension.

One limitation of the current research was the operationalization of CMV as serostatus rather than titers. A well-controlled CMV infection is likely to have different effects than one that is poorly controlled and, indeed, in previous studies, CMV antibody titers correlated with peak antibody response after influenza vaccination where serostatus did not (den Elzen et al., 2011; Furman et al., 2015; Trzonkowski et al., 2003). CMV antibody titers also correlated with markers of immune activation (de Pablo-Bernal et al., 2015; Trzonkowski et al., 2003). The age of the archived samples in the present study (dating back to 2001) suggested that serostatus could be more reliably measured than antibody titer; however, future research should examine both CMV serostatus and titers. It is also unknown when older adults in the current sample first contracted CMV. How long the host immune system has been working to "control" the latent virus could have differential effects on immunosenescence (Bosch et al., 2013). In addition, CMV was the only latent viral infection examined. Others (e.g., Epstein-Barr virus) are also common in older adults and may further impact immune function and health. For example, an aggregate index of latent infections correlated with cognitive function in young and middle adulthood (Gale, Erickson, Berrett, Brown, \& Hedges, 2016), and such an index may have more predictive power for immune senescence than a single infection. Finally, markers of B and T cell function were not directly assessed in the current study, but may explain part of the effects of CMV on antibody responses. 
These findings contribute to a growing body of research demonstrating the role of CMV on immune senescence. To our knowledge, this is the first study that has examined the joint effects of beta blockade and CMV serostatus on antibody responses and inflammation in older adults. Older adults with CMV who are also taking beta-blockers in a naturalistic context may be more vulnerable to negative effects of age on peak antibody response. These effects may differ from experimental beta blockade and suggest continued exploration of the contexts in which CMV affects immunosenescence in older adults.

\section{Acknowledgments}

This research was supported by the National Institute on Aging (R01-AG026307, K02-033629, P50-AG05144, M01-RR02602).

\section{References}

Aiken, LS., West, SG. Multiple Regression: Testing and Interpreting Interactions. Newbury Park, CA: Sage; 1991.

Badami KG, McQuilkan-Bickerstaffe S, Wells JE, Parata M. Cytomegalovirus seroprevalence and 'cytomegalovirus-safe' seropositive blood donors. Epidemiol. Infect. 2009; 137:1776-1780. [PubMed: 19480727]

Baker JG, Hill SJ, Summers RJ. Evolution of $\beta$-blockers: from anti-anginal drugs to ligand-directed signalling. Trends Pharmacol. Sci. 2011; 32:227-234. [PubMed: 21429598]

Bartlett DB, Firth CM, Phillips AC, Moss P, Baylis D, Syddall H, Lord JM. The age-related increase in low-grade systemic inflammation (inflammaging) is not driven by cytomegalovirus infection. Aging Cell. 2012; 11:912-915. [PubMed: 22708923]

Beyer W, Palache A, Lüchters G, Nauta J, Osterhaus A. Seroprotection rate, mean fold increase, seroconversion rate: which parameter adequately expresses seroresponse to influenza vaccination? Virus Res. 2004; 103:125-132. [PubMed: 15163500]

Bosch, JA., Rector, JL., Turner, JE., Riddell, NE., o'Hartaigh, B., Burns, VE. Psychoneuromicrobiology: cytomegalovirus infection as a putative link between stress, aging, and immunity. In: Bosch, JA.Phillips, AC., Lord, JM., editors. Immunosenescence: Psychosocial and Behavioral Determinants. New York, NY: Springer; 2013. p. 81-100.

Britt, W. Manifestations of human cytomegalovirus infection: proposed mechanisms of acute and chronic disease. In: Shenk, TE., Stinski, MF., editors. Human Cytomegalovirus. Berlin: Springer; 2008. p. 417-470.

Buisman AM, De Rond CGH, Öztürk K, Ten Hulscher HI, Van Binnendijk RS. Long-term presence of memory B-cells specific for different vaccine components. Vaccine. 2009; 28:179-186. [PubMed: 19799844]

Clark DO, Von Korff M, Saunders K, Baluch WM, Simon GE. A chronic disease score with empirically derived weights. Med Care. 1995; 33:783-795. [PubMed: 7637401]

Cohen HJ, Harris T, Pieper CF. Coagulation and activation of inflammatory pathways in the development of functional decline and mortality in the elderly. Am. J. Med. 2003; 114:180-187. [PubMed: 12637131]

Darvishian M, Gefenaite G, Turner RM, Pechlivanoglou P, Van der Hoek W, Van den Heuvel ER, Hak E. After adjusting for bias in meta-analysis seasonal influenza vaccine remains effective in community-dwelling elderly. J Clin. Epidemiol. 2014; 67:734-744. [PubMed: 24768004]

den Elzen WP, Vossen AC, Cools HJ, Westendorp RG, Kroes AC, Gussekloo J. Cytomegalovirus infection and responsiveness to influenza vaccination in elderly residents of long-term care facilities. Vaccine. 2011; 29:4869-4874. [PubMed: 21497631]

Delabre RM, Salez N, Lemaitre M, Leruez-Ville M, De Lamballerie X, Carrat F. Antibody persistence and serological protection among seasonal 2007 influenza A (H1N1) infected subjects: Results from the FLUREC cohort study. Vaccine. 2015; 33:7015-7021. [PubMed: 26387434] 
Dong XM, Cai R, Yang F, Zhang YY, Wang XG, Fu SL, Zhang JR. Predictive value of plasma $\beta 2$ microglobulin on human body function and senescence. Eur. Rev. Med. Pharmacol. Sci. 2016; 20:2350-2356. [PubMed: 27338061]

Effros, RB. Stress and immune system aging. In: Segerstrom, SC., editor. Oxford Handbook of Psychoneuroimmunology. New York, NY: Oxford University Press; 2012. p. 63-76.

Effros RB, Dagarag M, Spaulding C, Man J. The role of CD8+ T-cell replicative senescence in human aging. Immunol Rev. 2005; 205:147-157. [PubMed: 15882351]

Ershler WB, Keller ET. Age-associated increased interleukin-6 gene expression, late-life diseases, and frailty. Annu. Rev. Med. 2000; 51:245-270. [PubMed: 10774463]

Firth C, Harrison R, Ritchie S, Wardlaw J, Ferro CJ, Starr JM, Moss P. Cytomegalovirus infection is associated with an increase in systolic blood pressure in older individuals. QJM hcw026. 2016 epub ahead of print.

Forsey RJ, Thompson JM, Ernerudh J, Hurst TL, Strindhall J, Johansson B, Wikby A. Plasma cytokine profiles in elderly humans. Mech Ageing Dev. 2003; 124:487-493. [PubMed: 12714257]

Frasca D, Blomberg BB. Aging, cytomegalovirus (CMV) and influenza vaccine responses. Hum. Vaccin. Immunother. 2016; 12:682-690. [PubMed: 26588038]

Frasca D, Diaz A, Romero M, Landin AM, Blomberg BB. Cytomegalovirus (CMV) seropositivity decreases B cell responses to the influenza vaccine. Vaccine. 2015; 33:1433-1439. [PubMed: 25659271]

Freeman ML, Sheridan BS, Bonneau RH, Hendricks RL. Psychological stress compromises CD8+ T cell control of latent herpes simplex virus type 1 infections. J. Immunol. 2007; 179:322-328. [PubMed: 17579052]

Fulop T, Dupuis G, Baehl S, Le Page A, Bourgade K, Frost E, Cunnane S. From inflamm-aging to immune-paralysis: a slippery slope during aging for immune-adaptation. Biogerontology. 2016; 17:147-157. [PubMed: 26472173]

Furman D, Jojic V, Sharma S, Shen-Orr SS, Angel CJ, Onengut-Gumuscu S, Dekker CL. Cytomegalovirus infection enhances the immune response to influenza. Sci. Transl. Med. 2015; 7:81ra43.

Gale SD, Erickson LD, Berrett A, Brown BL, Hedges DW. Infectious disease burden and cognitive function in young to middle-aged adults. Brain Behav. Immun. 2016; 52:161-168. [PubMed: 26598104]

Gebhardt BM, Kaufman HE. Propranolol suppresses reactivation of herpesvirus. Antiviral Res. 1995; 27:255-261. [PubMed: 8540747]

Koch S, Larbi A, Oezcelik D, Solana R, Gouttefangeas C, Attig S, Pawelec G. Cytomegalovirus Infection. Ann. N. Y. Acad. Sci. 2007; 1114:23-35. [PubMed: 17986574]

Lopez-Vergès S, Milush JM, Schwartz BS, Pando MJ, Jarjoura J, York VA, Norris PJ. Expansion of a unique CD57+ NKG2Chi natural killer cell subset during acute human cytomegalovirus infection. Proc. Natl. Acad. Sci. 2011; 108:14725-14732. [PubMed: 21825173]

McHeyzer-Williams, LJ., McHeyzer-Williams, MG. Memory B cell evolution: B cell biology. In: Gupta, S.Alt, FW.Cooper, MD.Melchers, F., Rajewsky, K., editors. Mechanisms of Lymphocyte Activation and Immune Regulation XI. US: Springer; 2007. p. 31-45.

O’Connor MF, Bower JE, Cho HJ, Creswell JD, Dimitrov S, Hamby ME, Sloan EK. To assess, to control, to exclude: Effects of biobehavioral factors on circulating inflammatory markers. Brain Behav. Immun. 2009; 23:887-897. [PubMed: 19389469]

Ohmit SE, Petrie JG, Cross RT, Johnson E, Monto AS. Influenza hemagglutination-inhibition antibody titer as a correlate of vaccine-induced protection. J. Infect. Dis. 2011; 204:1879-1885. [PubMed: 21998477]

Olsson J, Wikby A, Johansson B, Löfgren S, Nilsson B-O, Ferguson FG. Age-related change in peripheral blood T-lymphocyte subpopulations and cytomegalovirus infection in the very old: The Swedish longitudinal OCTO immune study. Mech. Ageing Dev. 2001; 121:187-201.

de Pablo-Bernal RS, Cañizares J, Rosado I, Galvá MI, Alvarez-Ríos AI, Carrillo-Vico A, Ramos R. Monocyte phenotype and polyfunctionality are associated with elevated soluble inflammatory markers, cytomegalovirus infection, and functional and cognitive decline in elderly adults. J. Gerontol. A Biol. Sci. Med. Sci. 2015; 71:610-618. [PubMed: 26286603] 
Pawelec G, Larbi A, Derhovanessian E. Senescence of the human immune system. J. Comp. Pathol. 2010; 142:S39-S44. [PubMed: 19897208]

Perk J, De Backer G, Gohlke H, Graham I, Reiner Ž, Verschuren M, Deaton C. European Guidelines on cardiovascular disease prevention in clinical practice (version 2012). Eur. Heart J. 2012; 33:1635-1701. [PubMed: 22555213]

Phillips AC, Carroll D, Khan N, Moss P. Cytomegalovirus is associated with depression and anxiety in older adults. Brain Behav. Immun. 2008; 22:52-55. [PubMed: 17703915]

Prösch S, Wendt CE, Reinke P, Priemer C, Oppert M, Krüger DH, Döcke W-D. A novel link between stress and human cytomegalovirus (HCMV) infection: sympathetic hyperactivity stimulates HCMV activation. Virology. 2000; 272:357-365. [PubMed: 10873779]

Qato DM, Alexander GC, Conti RM, Johnson M, Schumm P, Lindau ST. Use of prescription and overthe-counter medications and dietary supplements among older adults in the United States. JAMA. 2008; 300:2867-2878. [PubMed: 19109115]

Salvioli S, Monti D, Lanzarini C, Conte M, Pirazzini C, Giulia Bacalini M, Bucci L. Immune system, cell senescence, aging and longevity-inflamm-aging reappraised. Curr. Pharm. Des. 2013; 19:1675-1679. [PubMed: 23589904]

Sanders, V., Kasprowicz, D., Kohm, A., Swanson, M. Neurotransmitter receptors on lymphocytes and other lymphoid cells. In: Ader, R.Felton, DL., Cohen, N., editors. Psychoneuroimmunology. third. San Diego, CA: Academic Press; 2001. p. 161-196.

Segerstrom SC, Hardy JK, Evans DR, Greenberg RN. Vulnerability, distress, and immune response to vaccination in older adults. Brain Behav. Immun. 2012; 26:747-753. [PubMed: 22062498]

Simons R, Reynolds H. Altered immune status in the elderly. Semin. Respir. Infect. 1990; 5:251-259. [PubMed: 2093970]

Singer, JD. Fitting individual growth models using SAS PROC MIXED. In: Moskowitz, DS., Hershberger, SL., editors. Modeling intraindividual variability with repeated measures data: Methods and applications. New Jersey: Lawrence Erlbaum Associates; 2002. p. 135-170.

Singer, JD., Willett, JB. Applied longitudinal data analysis: Modeling change and event occurrence. New York, NY: Oxford University Press; 2003.

Skowronski DM, Tweed SA, De Serres G. Rapid decline of influenza vaccine-induced antibody in the elderly: is it real, or is it relevant? J. Infect. Dis. 2008; 197:490-502. [PubMed: 18275271]

Smith LK, He Y, Park JS, Bieri G, Snethlage CE, Lin K, Wheatley EG. [beta] 2-microglobulin is a systemic pro-aging factor that impairs cognitive function and neurogenesis. Nat. Med. 2015; 21:932-937. [PubMed: 26147761]

Sridhar S, Begom S, Hoschler K, Bermingham A, Adamson W, Carman W, Lalvani A. Longevity and determinants of protective humoral immunity after pandemic influenza infection. Am. J. Respir. Crit. Care Med. 2015; 191:325-332. [PubMed: 25506631]

Stewart Coats AJ, Ho GF, Prabhash K, Haehling S, Tilson J, Brown R, Anker SD. Espindolol for the treatment and prevention of cachexia in patients with stage III/IV non-small cell lung cancer or colorectal cancer: a randomized, double-blind, placebo-controlled, international multicentre phase II study (the ACT-ONE trial). J. Cachexia Sarcopenia Muscle. 2016; 7:355-365. [PubMed: 27386169]

Strindhall J, Ernerudh J, Mörner A, Waalen K, Löfgren S, Matussek A, Bengner M. Humoral response to influenza vaccination in relation to pre-vaccination antibody titres, vaccination history, cytomegalovirus serostatus and CD4/CD8 ratio. Infect. Dis. (Lond.). 2016; 48:436-442. [PubMed: 27030916]

Trzonkowski P, Myśliwska J, Szmit E, Wieckiewicz J, Łukaszuk K, Brydak LB, Myśliwski A. Association between cytomegalovirus infection, enhanced proinflammatory response and low level of anti-hemagglutinins during the anti-influenza vaccination — an impact of immunosenescence. Vaccine. 2003; 21:3826-3836. [PubMed: 12922116]

van de Berg PJ, Heutinck KM, Raabe R, Minnee RC, La Young S, Bemelman FJ, Ineke J. Human cytomegalovirus induces systemic immune activation characterized by a type 1 cytokine signature. J. Infect. Dis. 2010; 202:690-699. [PubMed: 20632887] 
Wald A, Selke S, Magaret A, Boeckh M. Impact of human cytomegalovirus (CMV) infection on immune response to pandemic $2009 \mathrm{H} 1 \mathrm{~N} 1$ influenza vaccine in healthy adults. J. Med. Virol. 2013; 85:1557-1560. [PubMed: 23852679]

Wang ECY, Taylor-Wiedeman J, Perera P, Fisher J, Borysiewicz L. Subsets of CD8+, CD57+ cells in normal, healthy individuals: correlations with human cytomegalovirus (HCMV) carrier status, phenotypic and functional analyses. Clin. Exp. Immunol. 1993; 94:297-305. [PubMed: 7693383]

WHO. [accessed August 22, 2016] WHO recommendations on the composition of influenza virus vaccines. 2016. Retrieved from http://www.who.int/influenza/vaccines/virus/recommendations/en/

Zhou L, Li Y, Li X, Chen G, Liang H, Wu Y, Ouyang W. Propranolol attenuates surgical stressinduced elevation of the regulatory $\mathrm{T}$ cell response in patients undergoing radical mastectomy. J. Immunol. 2016; 196:3460-3469. [PubMed: 26969754] 


\section{Highlights}

- $\quad$ Beta-blocker (BB) use and age may affect associations between CMV and immunity.

- In $\mathrm{CMV}+\mathrm{BB}+$ adults, age was negatively associated with short term antibody response.

- $\quad \mathrm{CMV}-\mathrm{BB}-$ adults had the highest antibody persistence in the long term.

- $\quad$ CMV serostatus was not associated with beta-2 microglobulin or interleukin-6. 


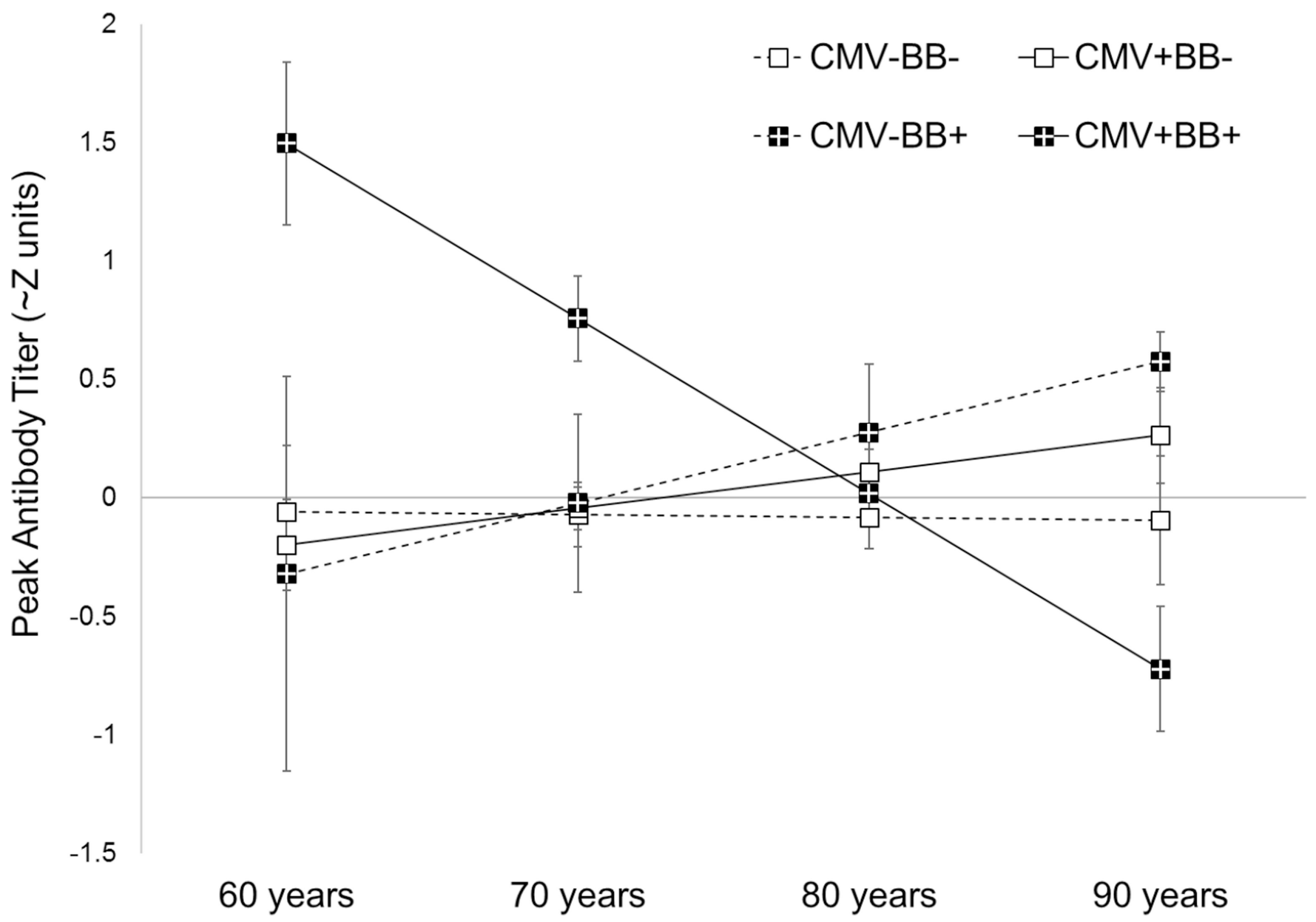

Figure 1.

Peak antibody simple slopes from decomposition of the interaction among chronological age, beta-blocker use (on + / off -), and CMV serostatus (seropositive +/seronegative -). Peak antibody titers are in approximate $\mathrm{Z}$ units, or the number of standard deviations from the mean $=0$. Error bars represent standard errors of the estimates. 


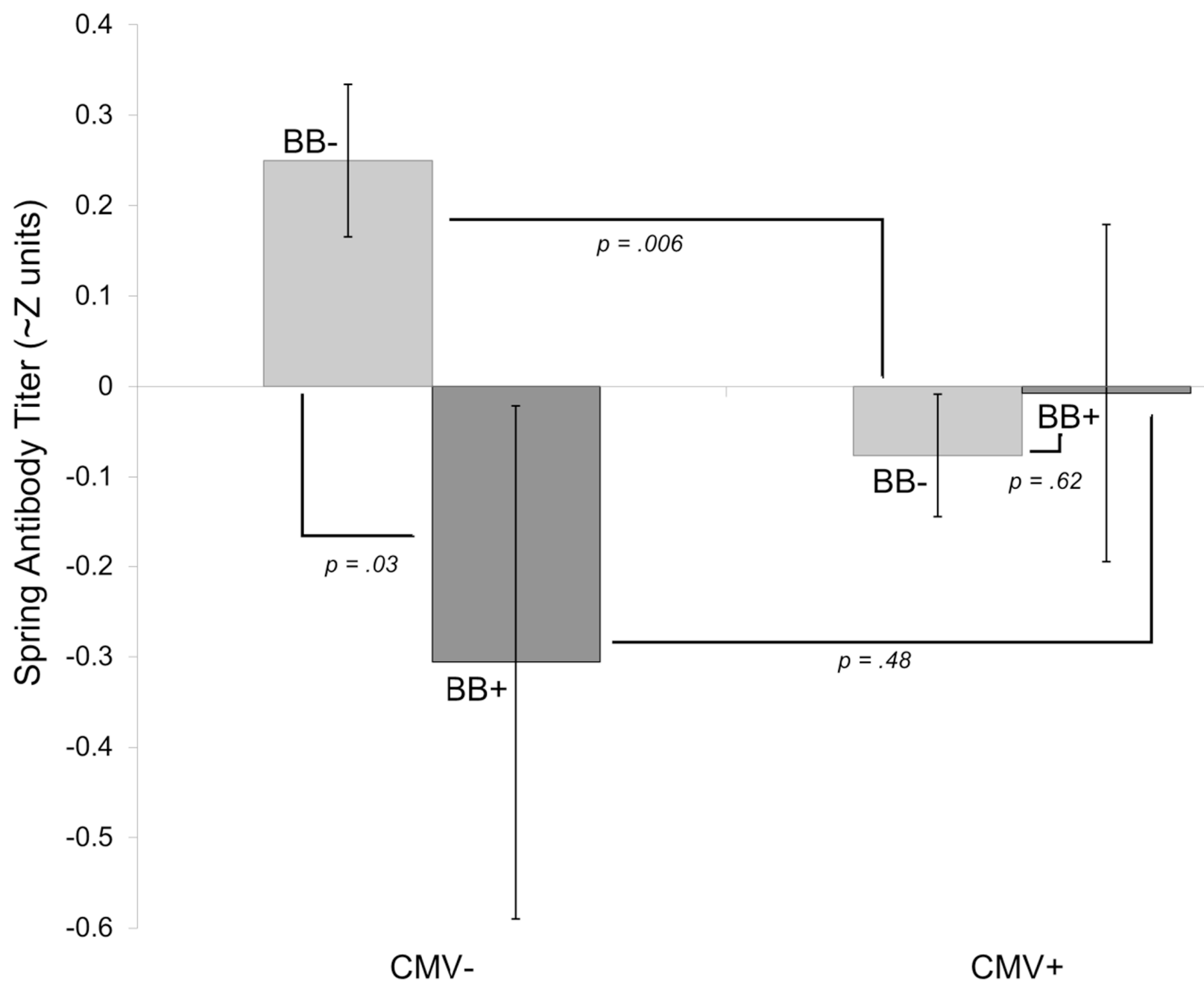

Figure 2.

Antibody persistence model estimates with $p$ values from simple main effect decomposition of the interaction between CMV serostatus (seronegative - /seropositive + ) and beta-blocker use (on $+/$ off - ). Each bar represents the estimated spring antibody titer (in approximate $\mathrm{Z}$ units, or the number of standard deviations from the mean $=0$ ) for each combination of CMV serostatus and beta-blocker use. Each bar starts at 0 and extends to the approximate $\mathrm{Z}$ unit for the designated combination. Error bars represent standard errors of the estimates. 


\section{Table 1}

Number of people, person-year observations, and mean ages at CMV/Beta Blockade combinations

\begin{tabular}{cccc}
\hline & CMV seronegative & CMV seropositive & Total \\
\hline \multirow{2}{*}{ BB - } & $\mathrm{N}=24, \mathrm{PY}=74$ & $\mathrm{~N}=51, \mathrm{PY}=182$ & $\mathrm{~N}=75, \mathrm{PY}=256$ \\
& $\mathrm{Age}_{\mathrm{M}}=75$ & $\mathrm{Age}_{\mathrm{M}}=75$ & \\
& $\mathrm{~N}=6, \mathrm{PY}=15$ & $\mathrm{~N}=17, \mathrm{PY}=54$ & $\mathrm{~N}=23, \mathrm{PY}=69$ \\
BB + & $\mathrm{Age}_{\mathrm{M}}=76$ & $\mathrm{Age}_{\mathrm{M}}=77$ & \\
& $\mathrm{~N}=30, \mathrm{PY}=89$ & $\mathrm{~N}=68, \mathrm{PY}=236$ & $\mathrm{~N}=89, \mathrm{PY}=325$ \\
\hline
\end{tabular}

Note. $\mathrm{N}=$ number of people; $\mathrm{PY}=$ number of person-year observations; $\mathrm{BB}=$ Beta-blocker use, indicated by off - / on + . Although beta-blocker use was time-varying, for the purposes of this table, the $n=7$ individuals who were more often off beta-blockers than on are represented as "off", and the $n=5$ individuals who were more often on beta-blockers than off are represented as "on". 


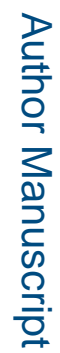

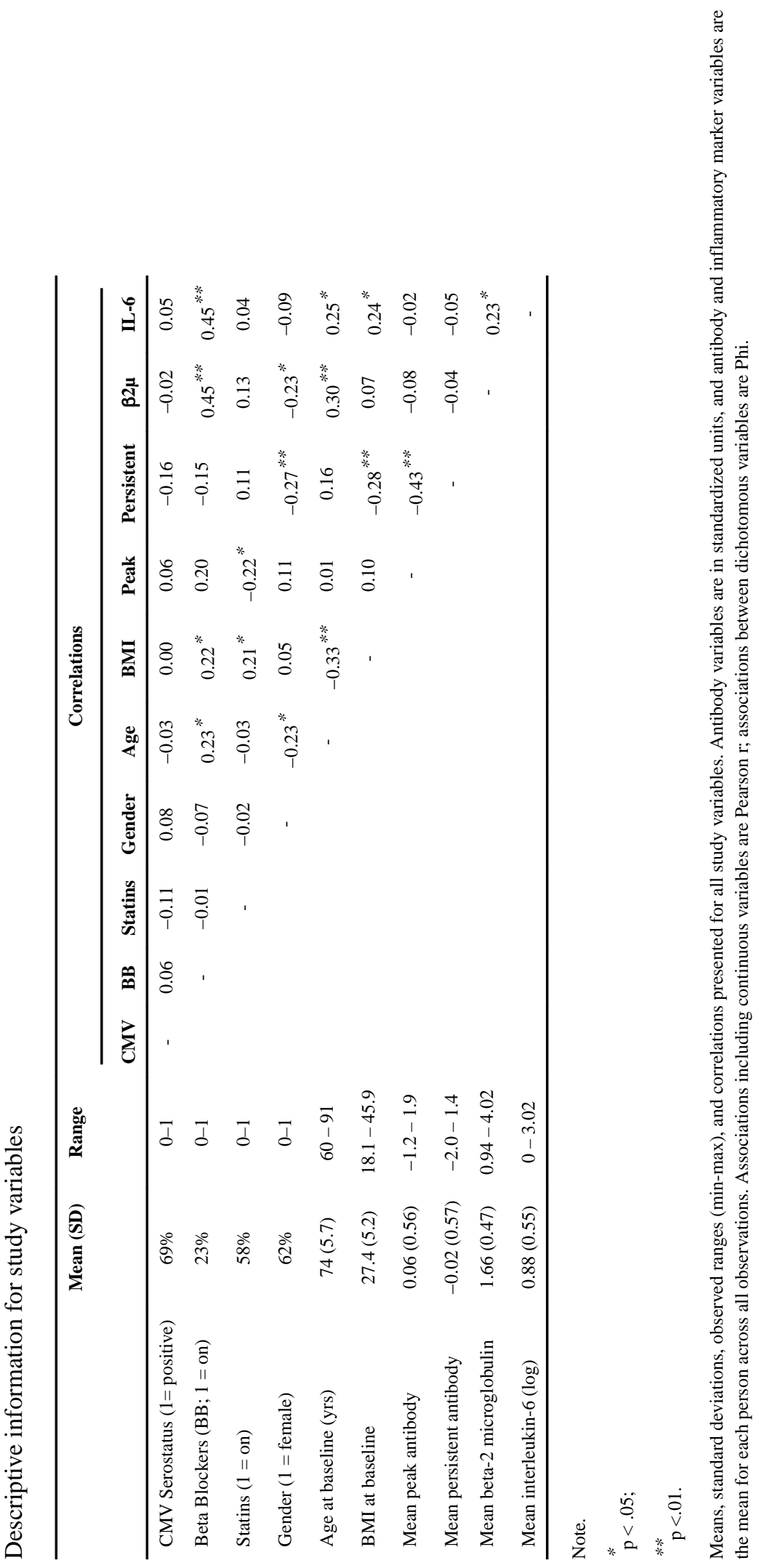

Brain Behav Immun. Author manuscript; available in PMC 2018 March 01. 